\title{
АВТОБІОГРАФІЧНА ПАМ'ЯТЬ У СТРУКТУРІ ЩОДЕННИКОВОГО ДИСКУРСУ
}

\author{
СВІТЛАНА ІГНАТЬЕВА \\ Національний технічний університет „Дніпровська політехніка”, Дніпро - Україна \\ sv.ihnatieva@gmail.com; ORCID: 0000-0003-2217-4610 \\ PAMIEĆ AUTOBIOGRAFICZNA \\ W STRUKTURZE DYSKURSU PAMIĘTNIKARSKIEGO
}

SWITŁANA IHNATIEWA

Narodowy Uniwersytet Techniczny „Politechnika Dniprowska”, Dnipro — Ukraina

STRESZCZENIE. W artykule poddano analizie pamięć autobiograficzna jako proces spowodowany chęcią pamiętnikarza-adresanta głębiej wniknąć w swoje wewnętrzne „Ja”, jak najlepiej zrozumieć samego siebie, swoją przeszłość, osiągnąć sens istnienia. Określono subiektywne czynniki, które wpływają na zdolność pamięci do transformacji. Skoncentrowano uwagę na sytuacji medialnej pamięci autobiograficznej w strukturze dyskursu pamiętnikarskiego, wskazano na jej zdolność identyfikacji autora - nadawcy wypowiedzi. Przedstawiono niezbędne dla wielostronnego rozumienia machanizmów pamięci autobiograficznej funkcje intersubiektywną, intrasubiektywną oraz egzystencjalną, wyodrębniono markery językowe, które biorą aktywny udział w dyskursie pamiętnikarskim. Dyskurs pamiętnikarski omówiono jako szczególny rodzaj dialogu pamiętnikarza z samym sobą, z umownym nadawcą-odbiorcą, epoką, przyszłością.

Słowa kluczowe: pamięć autobiograficzna, pamięć indywidualna, predykaty pamięci, proces zapamiętywania, dyskurs pamiętnikarski.

\section{AUTOBIOGRAPHICAL MEMORY \\ IN THE STRUCTURE OF DIARY DISCOURSE}

\section{SVITLANA IHNATYEVA \\ National Technical University "Dnipro Polytechnics", Dnipro - Ukraine}

ABSTRACT. The article deals with the analysis of an autobiographical memory as a process caused by the desire of the diary-addresser to penetrate into his inner self more deeply, to understand himself, his past, and to comprehend the meaning of his being. The subjective factors influencing its ability to transform have been revealed. The attention has been focused on the medial position of an autobiographical memory in the structure of a diary discourse, its meaning in identifying the author-communicant has been emphasized. The intersubjective, intrasubjective and extrasentative functions necessary for a versatile understanding of the mechanisms of autobiographical memoryare have been identified. The language markers that actively 'work' in the diary discourse have been singled out. The diary discourse is considered as a special dialogue of the diary writer with himself, with the imaginary communicantrecipient, the era, the future.

Key words: autobiographical memory, autobiographical information, individual memory, memory predicates, process of memorization, diary discourse.

$\prod$

ізнання дійсності неможливе без сприйняття інформації, що надходить до мовця ззовні. У щоденниковому дискурсі пам'ять становить складний психічний процес відображення досвіду діариста через засвоєння, збереження та подальше відтворення обставин його особистого життя й пізнаваль- 
ної діяльності загалом. Завдяки пам'яті людина зберігає досягнення попередніх поколінь, оволодіває продуктами національної культури. Людська пам'ять слугує сполучною ланкою між минулим, теперішнім і майбутнім. Погоджуємося із зафіксованим у діаріуші Олесі Волі „Василь Рубан: «У в'язнииі я зрозумів, що людська пам'ять навіть важсливіша за винахід письма...»" (Воля 2011, с. 780). Утрачаючи пам'ять, людина не лише забуває про своє минуле, а й утрачає здатність повноцінно жити, оскільки кожна форма пам'яті становить основу життя мовця.

У цьому дослідженні розглядаємо пам'ять як міцний ланцюжок, що виникає між людиною - автором щоденникового тексту - i довкіллям, у якому вона жила. Пам'ять не тільки зберігає у свідомості людини певні враження, а й слугує поштовхом і джерелом для їхнього відтворення. Саме пам'ять $\epsilon$ тим символічним стрижнем, що пролягає через віки, роки й покоління, нанизує на історію радісні й сумні, щасливі й болючі події, які трапилися в житті діариста й стали для нього знаковими.

Щоденниковий дискурс містить інформацію про минуле діариста, його роздуми разом з емоційними оцінками щодо подій далеко минулих і тих, що відбулися 3 ним нещодавно. Зауважимо, що “Я” оповідувача $є$ не тільки суб'єктом мовлення, але й об'єктом для вираження своїх думок та їхнього фіксування на папері. Ще М. Бахтін стверджував, що об'єктом автобіографічної прози можна вважати „не тільки світ свого минулого у світлі теперішньої зрілої свідомості й розуміння, збагачених часовою перспективою, але й свою минулу свідомість і розуміння цього світу (дитячу, юнацьку, молоду)", наголошуючи на думці про те, що минула свідомість $€$,,таким самим предметом зображення, як і об'єктивний світ минулого. Ці дві свідомості, між якими десятиліття, які бачать один і той самий світ, не розділені грубо... вони, навпаки, одухотворюють цей предмет, змушують перебувати його в динаміці, наповнюють людяністю".

У сучасних дослідженнях щзоденникову пам'ять розглядають як основу самосвідомості особистості, iii "Я-концепції”', значення полягає в здатності людини фіксувати й зберігати такі події, які вона усвідомлює як частину власної історії.

Загалом оперування поняттям пам'ять вимагає його узгодження з існуючими дефініціями, оскільки дослідники витлумачують його по-різному. У дослідженнях Ю. Лотмана пам'ять розглянуто як знакову систему, здатну зберігати й відтворювати знакову інформацію ${ }^{3}$. Дефініцію поняття пам'ять розглянуто і в Лінгвістичній енциклопедіï О. Селіванової, а також акцентовано увагу на когнітивній здатності пам'яті „утримувати й систематизовано інтегрувати в мозку людини різнобічну інформацію, отриману в результаті переробки чуттєвого та внутрішнього рефлективного досвіду"“. Виокремлено ще такий важливий аспект пам'яті, як те, що вона „опосередковує набуття, організацію та збереження знань - інформації, наявної в мисленні людини, що служить для розв'язання нею інтелектуальних і мовних завдань, застосовується в повсякденній пізнавальній і мовленнєвій діяльності, зумовлює поведінку людини"”.

${ }^{1}$ М. М. Бахтин, Проблема речевых жанров, [в:] Эстетика словесного творчества, сост. С. Г. Бочаров, 2-е изд., Москва 1986, с. 398.

${ }^{2}$ В. В. Нуркова, Свершенное продолжается: Психология автобиографической памяти личности, Москва 2000; В. В. Нурко ва, Зеркало с памятью. Феномен фотографии: культурноисторический анализ, Москва 2006.

${ }^{3}$ Ю. М. Лотман, Семиосфера: культура и взрыь, Санкт-Петербург 2000, с. 203.

${ }^{4}$ О. О. Селів анов а, Лінгвістична енциклопедія, Полтава-Київ 2010, с. 527.

5 Там само, с. 527 
Інший дослідник, Юрій Ковалів, у Літературознавчій енциклопедії визначає пам'ять як „процес відображення, закріплення й збереження інформації, а також впізнавання й відтворення запам'ятованого". Психологи уточнюють диференційні параметри цього поняття, називаючи пам'ять „процесом організації та збереження минулого досвіду, що дає змогу його повторно використовувати у своїй діяльності або повертатися у сферу свідомого" .

Вагомим у вивченні пам'яті є дослідження Н. Брагіної, яка фокусує увагу на комунікативній властивості концепту пам'ять, указуючи на надважливість образу минулого в щоденниковому дискурсі й пропонуючи його вивчення не лише як ретроспективу або поштовх до написання / ненаписання, але і як бага-

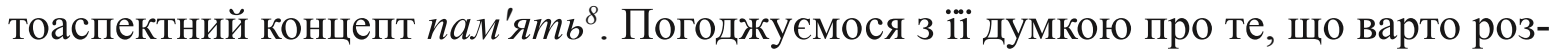
глядати пам'ять як співрозмовника у фокусі діалогу з Alter Ego, ,іншим Я”, що репрезентує минуле (“Я-минуле”). Такий діалог постає як відверта розмова зі своєю душею; а пам'ять у цій ситуації „має голос і здатна розмовляти”, а часом i сперечатися з власним Ego. Виникає діалог, мета якого - вплинути на нього: переконати, завірити, повідомити про щось, дати відповідь, змусити завагатися тощо. Комунікація відбувається вербально, а суперечність між теперішнім актуальним і минулим плюсквамперфектним, як уважає Н. Брагіна, може персоніфікуватися й виражатися в мові через зв'язок “Я” людини з ії пам'яттю9.

Лінгвістичний аспект вивчення пам'яті передбачає лінгвокультурологічний, дискурс- чи текстоцентричний підхід, згідно з яким Т. Космеда надає перевагу подвійному єству Ego, або “Я-образу”, оскільки Еgo постійно спілкується з іншим Ego (Alter Ego), що спирається на інтуїцію, емоції й почуття, є вираженням душі.

Важливо те, що пам'ять - складний пізнавальний процес у діарійнокомунікативному просторі. Ї̈̈ різноаспектне вивчення дає змогу глибше зрозуміти внутрішню природу “Я-образу”, процесів пізнання, структурування діяльності та упорядкування досвіду. Для усвідомлення природи пам'яті одним з важливих уважаємо питання іiї вербалізації в щоденниковому дискурсі, оскільки саме мова діаріуша $\epsilon$ основною і природною формою існування "Я-образу", через неї можна здійснити й найбільш повний доступ саме до сутності пам'яті.

Пам'ять у щоденниковому дискурсі - це не тільки фіксування власних думок на папері, прагнення поділитися досвідом, залишити по собі спогад, а дія, спричинена передусім бажанням зрозуміти себе, своє минуле, осягнути сенс буття. Пам'ять пов'язує минуле особистості з їі теперішнім і майбутнім, вона $є$ важливим пізнавальним чинником, завдяки якому кожне покоління передає свої знання наступному.

У сучасному українському щоденниковому дискурсі якнайповніше виявляється здатність людини до запам'ятовування, збереження та відновлення в пам'яті інформації про минуле. Точність, об'єктивність зафіксованого у прямій залежності саме від властивостей людської пам'яті. Інтерес до вивчення автобіографічної пам'яті щоденникаря видається досить аргументованим,

6 Літературознавча енцииклопедія, у 2 томах, Київ 2007, т. 2, авт.-уклад. Ю. І. Ковалів, c. 174.

${ }^{7}$ Краткий психологический словарь, общ. ред. А. В. Петровского, М. Г. Ярошевского, Ростов-на-Дону 1998, с. 240.

${ }^{8}$ Н. Г. Брагина, Память в языке и культуре, Москва 2007, с. 93

${ }^{9}$ Т. Космеда, Ego i Alter Ego Tapaca Шевченка в комунікативному просторі щоденникового дискурсу, Дрогобич 2012, с. 81. 
оскільки, $з$ одного боку, автобіографічна інформація якнайповніше розкривається в щоденниковому дискурсі й сприймається комунікантом-реципієнтом як найбільш точна, правильна, хоч іноді вона трансформується, викривлюється під дією суб'єктивних чинників; з другого - звернення до власних автобіографічних спогадів, відтворення їх у щоденниковому дискурсі змушує діариста по-новому пережити важливі події свого життя й слугує важливим інструментом для зняття психологічної напруги. Діарист, спілкуючись із собою, має можливість простежити зміни в собі, побачити трансформацію власних переконань, поглядів на події, що відбулися з ним у минулому.

У контексті дослідження процесів, що їх здійснює пам'ять, наголошуємо на необхідності осмислення феномена індивідуальної пам'яті $і$, а щоденниковий дискурс розглядаємо як особливий діалог діариста із самим собою, уявним читачем, іншими творами, цілою епохою, майбутнім. Пам'ять є однією з найголовніших ознак, що характеризує щоденниковий дискурс. Як зауважує П. Сорока, „,дине, що не старіє - спогади, мемуари, чи не тому, щзо за своєю природою, за жанром вони приречені переборювати час, вони - саме переборення часу" (Cорока 2003, с. 106). Автобіографічна пам'ять у щоденниковому дискурсі є необхідним фактологічним підгрунтям (медіатором), що сприяє ідентифікації його автора. Насамперед вона виконує три важливі функції: а) інтерсуб'єктивну, що пов'язана із життям діариста як члена соціуму; б) інтрасуб'єктивну, що сприяє саморегуляції особистості діариста; в) екзестенційну, що необхідна діаристу для переживання та розуміння своєї винятковості.

Різнобічне дослідження щоденникового дискурсу вможливлює висновок про те, що в ньому виразно простежуються ретроспективний і проспективний аспекти функціонування пам'яті. Проспективна пам'ять спрямована, зрозуміло, у майбутнє, вона протиставляється ретроспективній пам'яті та сприяє утриманню інформації-наміру на майбутнє. Власне ретроспективність забезпечує подвійну точку зору діариста на події минулого, оскільки сучасний погляд накладає відбиток на давню реакцію щодо подій, про які згадується. Ретроспективна пам'ять уможливлюе “відфільтровування" інформації, що постає 3 пам'яті та дає змогу відтворювати іiі в завершеному вигляді. Ретроспективний і проспективний аспекти тісно пов'язані з вивченням автобіографічної пам'яті як багаторівневої лінгвопсихологічної системи ${ }^{10}$.

Феноменологія автобіографічної пам'яті залежить від місця матеріалу в структурі діяльності, що характеризує процес відтворення й пояснює пластичність спогадів ${ }^{11}$.

Для вивчення структури автобіорафічної пам'яті в проекції на щоденниковий дискурс приймаємо як базову модель М. Конвея. Це самореферениійна система пам'яті (Self-Memory System), згідно з якою в генезі щоденникового дискурсу беруть участь підструктури семантичної та епізодичної пам'яті разом 3 особистісними структурами - “Довготривалим Я” (Long-term Self) та “Працюючим Я” (Working Self). За моделлю М. Конвея, загальна система пам'яті продукує такі рівні феноменології автобіографічної пам'яті: 1) образно насичені епізоди; 2) узагальнені події; 3) життєві етапи; 4) цілісні життєві історії ${ }^{12}$.

${ }^{10}$ В. В. Нуркова, Психология, ред. В. В. Нуркова, Н. Б. Березанская, 2-е изд., перераб. и доп., Москва 2011, с. 350.

${ }^{11}$ Там же, с. 371

${ }^{12}$ M. A. Conway, J. A. Singer \& A. Tagini, The Self and Autobiographical Memory: Correspondence and Coherence, [v:] „Social Cognition”, 2004, 22(5), p. 491-529; M. A. Conway, Memory and self, [v:] „Journal Memory and Languagu”, 2005, 53, p. 594-628. 
Модель автобіографічної пам'яті, запропонована В. Нурковою, презентує цілісну особистісно-когнітивну систему з мікро- та макрорівнями, які між собою постійно взаємодіють ${ }^{13}$. Мікрорівень визначається структурно функційними одиницями, що набувають форми дискретних автобіографічних спогадів - “фотографічних", “важливих", “самовизначальних", “переломних”. Останній вирізняється особливою важливістю та фіксує кардинальні зміни в поведінці особистості, яка $є$ автором діаріуша. Щодо макрорівня, то його кваліфікуємо за допомогою інтегрованих культурних форм - життєвих етапів та особистісних життєвих історій. Саме макрорівень визначають “спогади-якорі”, що дають змогу діаристу конструювати себе як особистість, і “спогади-моделі”, що важливі для розуміння навколишнього світу, а ще вони сприяють правильному вибору життєвих орієнтирів у конкретній ситуації.

Життєпис діариста поряд із зображенням образів сучасників, історії його душі - почуттів, думок, ідей разом з оцінними кваліфікаторами - важливі складники, окреслені аксіологічним колом, стрижнем якого в щоденниковому дискурсі є людська пам'ять. Він дає змогу не тільки глибше зрозуміти життєві перепетії особистості діариста, а й визначити його інтелектуальну спроможність, передати атмосферу епохи з усвідомленням подієвого потоку життя, сповіді про минуле. Напр.: „Але де брати сил відбиватися від негідників? У Миколаєві, пишуть, уночі знесли пам'ятник Шевченкові. Як колись у 1937-му в Харкові «вкрадено» було погруддя Блакитного. Пригадую - їдемо на навчання, а в скверику пусто”"14 (Гончар, т. 3, с. 69). „Пригадую, що за тиждень - Великдень $і$ стає жаль, що не дотягую иі кілька днів, коли відкриті небеса" "I5 (Сорока 2006, с. 49); „Пригадується, иарська армія билася краще. Була краща дисципліна, краща виучка i було ще щось вічне, високе..." 16 (Довженко 2003, с. 261). Услід за О. Падучевою, до дієслів мисленнєвої діяльності відносимо ті, що пов'язані з набуттям, зберіганням або ж з утратою знань, а також із семантикою бажання отримати знання ${ }^{17}$. Великий тлумачний словник сучасної украӥнської мови пропонує такі значення дієслів, що означають процес мислення, - нагадувати, пригадувати: „1. перех. і неперех. Примушувати згадати про кого-, щонебудь. 2. Відновляти в пам'яті минулі події, явища, образи і т. ін.; згадувати"18; згадувати по семі каузативність - „1. відтворювати в пам'яті, свідомості, події, обставини, образи і т. ін. минулого, відновлювати уявлення про кого-, що-небудь" 19 .

Як правило, мова діариста насичена сигналами пригадування, тобто лексемами-дієсловами чи дієслівними конструкціями на зразок: пам'ятаю, $n p u-$ гадую, згадую, бачу як, чую як, i тепер бачу та ін. За допомогою цих сигналівпредикатів до опису реалістичної події сьогодення долучаються згадки про події, факти минулого. Саме такі конструкції й сигналізують про вибіркову роботу пам'яті. “Пам'ятати”, за Н. Ніколіною, — „мати знання про минуле / його

${ }^{13}$ В. В. Нуркова, Свершенное продолжается..., с. 373.

${ }^{14}$ О. Т. Гончар, Щоденники, у 3-х томах, упоряд. В. Д. Гончар, т. 1 (1943-1967), т. 2 (1968-1983), т. 3 (1984-1995), Київ 2002, 2003, 2004. - Далі в дужках указуємо прізвище письменника, том цього видання й конкретну сторінку.

${ }^{15}$ Петро Сорока, Застиглий вогонь. Денники 2006 року, Тернопіль 2007. - Далі в дужках указуємо прізвище письменника, рік цього видання й конкретну сторінку.

${ }^{16}$ О. Довженко, Вибрані твори, упоряд. та передм. І. Л. Михайлина, Харків 2003.

${ }^{17}$ Е. В. Падучева, Семантика вида и точка отсчета, [в:] „Известия АН СССР”, серия литературы и языка, Москва 1986, т. 45, № 5, с. 418.

${ }^{18}$ Великий тлумачний словник сучасної украӥнськоїмови, уклад. В. Т. Бусел, Київ 2004, с. 554.

19 Там само, с. 357 
набуття в акті «спогади», які залежать від свідомих зусиль суб'єкта"20. В українському щоденниковому дискурсі дефініція "пригадую” вирізняється специфічною функцією, закладеною в іiі семантиці, - надавати висловлюванню додаткової інформації, уточнювати іiі, пояснювати щось. Напр.: „Пригадую, щзо років двадиять тому мені потрапив до рук щзоденник одного письменника, який основну увагу зосередив на описах своїх недуг $і$ боротьби з ними, іншими словами кажучи, ие була книга про страждання тіла і емпіреї духу" (Сорока 2006, с. 49). „Пригадую, якось говорили Братковський з Мазепою про політику”21 (Сорока 2002, с. 126) та ін.

Для повного розуміння механізмів пам'яті виокремимо ті іiі мовні маркери, що “працюють” у щоденниковому дискурсі. Процеси пам'яті - пригадування, запам'ятовування, збереження, відтворення, забування з відповідним значенням містяться в поверхневій структурі щоденникового дискурсу. Найуживанішими $\epsilon$ предикати пам'ятати, згадувати із значенням 'тримати в пам'яті (у виразному, активному полі свідомості) будь-які знання, навички, уміння, мати можливість завжди реалізувати їх на практиці' 22.3 одного боку, цей предикат виражає процес збереження інформації, напр.: „Подзвонив П. Загребельний. Вітав. Згадав літа молодості” (Гончар, т. 3, с. 41). „Дивлюсь на нього $\boldsymbol{i}$ згадую відвідини Китаю в ранній ранок його нового життя, коли народи наші поставали в дружбі, шуо їй, здавалось, ніколи не минати... і ми згадуєм славного Мао Дуня, з яким ми заприязнились; згадуються інші люди, культурні, освічені, до яких я так і не міг в роки чвар відчути ворожості..." (Гончар, т. 3, с. 67). Цей процес пригадування і $є$ відтворенням у пам'яті. 3 іншого - безпосередньо процес пригадування чи відтворення інформації, порівн.: „Згадую як колись: Погуляв я циими степами - є щзо пригадати (Сорока 2002, с. 77); Сьогодні знову наснився Хміль $i$, прокинувшись, ще довго не міг вийти з того сновидіння. А потім пригадався бенкет у гетьмана" (Сорока 2002, с. 19). Окрім цього, процес пригадування частіше пов'язаний з подоланням труднощів, що виникають у житті діариста. Натомість власне процес відтворення інформації в щоденниковому дискурсі виражається дієсловом згадувати. Нерідко натрапляємо на такі конструкції з предикатом згадувати, напр.: „Вони згадували про нього, як про косаря доброго, щз, укосивши багато сінокосу, ліг надовго відпочити. Згадували про людей, головним чином, у плані їхніх робочих здібностей” (Довженко 2003, с. 240); „Згадую перший вечір війни: темно-темно. Кругле Поле. Ольга опирається на моє плече, а я боюся взяти ї̈ під руку"23 (Коваленко 2008, с. 204).

Важливо закцентувати, що в щоденниковому дискурсі простежуємо різне ставлення діариста до самого процесу “згадування". Зокрема, можна власне любити “згадувати”, згадувати із задоволенням або, навпаки, із сумом, напр.: „Про батька Іван Степанович навпаки любив згадувати $і$ незмінно висловлювався з великим пієтетом..." (Сорока 2002, с. 79). Можна, навпаки, не любити цей процес, напр.: „Мазепа не любив згадувати своє минуле, навіть коли був

${ }^{20}$ Н. А. Николина, Поэтика русской автобиографической прозы, 3 изд., стереотип., Москва 2017, с. 292.

${ }^{21}$ Петро Сорока, Душа при свічщъі (Діяріюш Федора Жученка), Тернопіль 2002. - Далі в дужках указуємо прізвище письменника, рік цього видання й конкретну сторінку.

22 Л. М. Васильев, Семантика русского глагола, Москва 1981, с. 166.

23 Л. М. Коваленко, „Ми - люди майбутнього, ми - не минулі”, статті, рецензіі, шоденники, спогади, поезї, листи, упоряд, Н. Л. Калениченко, О. Б. Поліщук, Дніпродзержинськ 2008. - Далі в дужках указуємо прізвище письменника, рік цього видання і конкретну сторінку. 
у доброму настрої і перебував у приємному товаристві" (Сорока 2002, с. 78). Часто щоденникар не хоче “згадувати” з якоїсь на те причини, напр.: „Tепер, на схилі віку, я більше не хочу ні думати, ні згадувати про неї, хоча за молодих літ вважав себе сином війни і не уявляв свого життя без кривавих січей" (Cорока 2002, с. 11); „Мама не любила згадувати. Нас привезли туди, - з-niд Biнниці, - а за добу погнали далі. Теж у Сілезії, ніби Кляйнмандерсдорф. Пригадую, там треба було увесь час уночі шикуватися..."24 (Танюк 2003: т. 2, с. 336).

Зважаючи на здатність пам'яті згадувати про щось епізодично, маючи перед собою неповну картину відтворюваного, діарист вдається до намагань змусити себе пригадати потрібну інформацію, напр.: „Нарешті такий довгий $i$ багатий на зустрічі та події день, що пізнім вечором намагаюся пригадати: ие було вчора чи сьогодні враниі?” (Сорока 2006, с. 47). В окремих випадках він демонструє досить активну роботу пам'яті, спроектовану навіть на не суттєву або й просто не потрібну інформацію, напр.: „Мене він іноді дивує. Все про всіх у місті, в Полтаві, в Києві, Москві знає. Різні плітки, звичайно. Звідки? I пам'ять на цей мотлох колосальна"25 (Малик 2010, с. 92).

Утім, існують різні види пам'яті, що розвиваються за своїми законами. Очевидно, є й необхідність дослідження механізмів пам'яті. І. Бондаревська, зокрема, наголошує на потребі вивчення „пам'яті як ресурсу (архіву) і високого обов'язку”, яка „трансформується в пам'ять як суперечливий процес", що дистанціюється від минулого. Зазначена дослідниця вважає, що можна по-справжньому осмислити феномен “місць пам'яті" 26. У щоденниковому дискурсі деколи за „показним шануванням приховано небажання пам'ятати, яке компенсують витраченим часом, наукою, мрією. Наш час $є$ часом безпам'ятства", — пише П. Нора ${ }^{27}$. Бінарне протиставлення пам'ятати - забувати сигналізує про бажання / небажання утримувати інформацію. Спроможність моделювання контрасту пам'ятати - забувати розглядаємо як можливість вербалізації експресії в щоденниковому дискурсі. Як слушно зауважує В. Чабаненко, „мовний контраст - це не просто об'єктивна лінгвістична універсалія, а ще й універсалія лінгвостилістична, породжена суб'єктивними мовотворчими зусиллями мовця в його пошуках експресивних засобів вислову"28. Мовленнєвим маркером процесу “забуття” в щоденниковому дискурсі є діалог щоденникаря зі своїм минулим. Він сам “торкається” свого минулого, ніби вириває окремі події, учинки, людські здобутки з полону часу й забуття. Порівн.: „І раптом я просіяв. Гордість і радість наповнили мене. І я побачив у вас героїв. Тоді я забув про все на світі, про смерть і про свою рану, про бомби і міни. Я встав і крикнув вам. Я зрозумів" (Довженко 2003, с. 251); ,Дурість моя в тім, що я весь час забував, що більшість міських людей - ие дурні і убогенькі" (Довженко 2003, с. 263).

${ }^{24}$ Л. С. Танюк, Лінія життя (зі щзоденників), у 2 томах, т. 2 (1971-1980), Харків 2004. Далі в дужках указуємо прізвище письменника, рік цього видання і конкретну сторінку.

${ }^{25}$ В. К. Малик, Синя книга, щуоденник (записки для себе). 1958-1998, упоряд. О. В. Сиченко, Н. О. Сиченко, Полтава 2010. - Далі в дужках указуємо прізвище письменника, рік цього видання і конкретну сторінку.

${ }^{26}$ I. Бондаревська, Пам'ятати $i$ забувати. Eсе про політику пам'яті, [в:] „Філософська думка”, 2014, № 6, с. 53.

27 П. Нора, Проблематика мест памяти, Франция-память, пер. с фр. Д. Хапаева, Санкт-Петербург 1999, с. 17-50.

28 Див.: В. А. Чабаненко, Стилістика експресивних засобів украӥнської мови, Запоріжжя 2002. 
Можна довго пам'ятати про щось незабутнє, порівн.: „Скільки пам'ятаю, вона завжди жила самотою",29 (Сорока 2003, с. 63), а можна швидко про все забувати: „Потужсила за ним якийсь час - i забула” (Сорока 2002, с. 22).

Предикати пам'яті, що вказують на необхідність збереження інформації чи, навпаки, ії втрату, характеризуються, як правило, часовими показниками: до цього часу, досі, сьогодні, вчора, завжди як зараз, уже, чомусь та ін., які свідчать про те, що з часом з певних суб'єктивних причин спогади можуть зберігатися, утрачатися, забуватися, напр.: „Досі згадують дніпропетровці ті кошмарні дні сваволі й тиску, залякувань та иькувань... Скільки чесних людей безневинно потерпіло за «Собор»! I скільки було руйначів, засліплених пристрастю браконьєрською, осоловілих від ненависті, здичавілих від розлюченості, жадаючих помсти... I тільки душам найсвітлішим, найдалекогляднішим дано було зрозуміти, що “Собор $C$ - невмирущий” (Гончар, т. 3, с. 38); „Уомусь згадалося вночі" (Гончар, т. 3, с. 12); „Згадалось сьогодні, як Ліля $і$ Леся виконували щось із Моцарта на сопілках (нове й таке чудове їхне захоплення)" (Гончар, т. 3, с. 34); „Завжди я пам'ятав, як прихильно поставився він [О. Корнійчук] до мене при виходi «Альn»" (Гончар, т. 3, с. 45). Незаперечним є те, що такі часові сигнали вносять у змістову частину висловлювань нову чи додаткову інформацію.

Найчастіше предикати пам'ятаю, згадую, пригадую окреслюють аксіологічне поле “пам'ять” у складнопідрядних реченнях з підрядними з'ясувальними. Вони містять інформацію про факти, процеси, явища, а також імена, назви, дублюючи поєднувальність 3 дієсловами на позначення дії сприйняття, напр.: „Пригадується, як подарував він мені рядок вірша Маланюкового, сповнений туги: „,Час, Господи, на самоту й покуту...” (Гончар, т. 3, с. 56).

Стилістичні прийоми, якими користується щоденникар, дають змогу уявити власне процес спомину, показати зв'язок пам'яті із сучасним сприйняттям інформації, провести образні паралелі між минулим і сучасним, позначені маркерами пам'ять, спогад, життя, час, минуле: „Згадувати про молодість, про щастя молодості - ие теж щастя” (Гончар, т. 3, с. 73); „Що залишилося у пам'яті? Може, нічого, крім сліпучого блиску сония і відчуття свободи, яке через рік уже й не згадати” (Сорока 2007, с. 55); „Слухаю враниі Тичину по радіо... Але, згадуючи попереднє життя поета, жахи, яких він набачився, багато шо можна йому простити...." (Гончар, т. 3, с. 42); „Але вже за моєї пам'яті стало «легше» $i$ «веселіме»” (Сорока 2007, с. 58); „Мабуть, тільки Шура й пам'ятає иеей родовід...” (Гончар, т. 3, с. 39); „Скільки пам'ятаю, ластівки завжди жили у нашому хліві, й сприймалися нами як щось дороге і рідне” (Сорока 2006, с. 59).

Важливим стилістичним прийомом у щоденниковому дискурсі, що виконує функцію пригадування, $\epsilon$ широковживані односкладні називні речення, які не містять сигналів пригадування, а дають змогу діаристу повернутися думками в минуле, порівн.: „Яновщина, теперішнє Гоголеве... Які краї! Музика полів, поезія ландшафтів... А ставок...” (Гончар, т. 2, с. 482); „Трійия! Зелене свято мого дитинства" (Гончар, т. 3, с. 299); „День Перемоги. Це наш другий Великдень! Солдатський” (Гончар, т. 3, с. 525); „Степ в кіниі червня. Тиша, повна тиша... Не гнітюча, не стояча, а якась спечифічно степова, дзюркотлива, жайворонкова..." (Гончар, т. 1, с. 156).

${ }^{29}$ Петро С орока, Рік подвійних райдуг. Денники 2002 року, Тернопіль 2003. - Далі в дужках указуємо прізвище письменника, рік цього видання й конкретну сторінку. 
Як засвідчує фактичний матеріал, послідовність номінантів зовнішньо не мотивована, вона тільки підсилює ті асоціативні зв'язки, які виникають в уяві діариста щодо згадуваних подій.

\section{Список використаної літератури}

Бахтин М. М., Проблема речевых жанров, [в:] Эстетика словесного творчества, сост. С. Г. Бочаров, 2-е изд., Москва 1986.

Бондаревська І., Пам'ятати $i$ забувати. Есе про політику пам'яті, [в:] „Філософська думка", 2014, № 6, с. 46-61.

Брагина Н. Г., Память в языке и культуре, Москва 2007.

Васильев Л. М., Семантика русского глагола, Москва 1981.

Великий тлумачний словник сучасної украӥнської мови, уклад. В. Т. Бусел, Київ 2004.

Воля Олесь, Щоденник. Сорок років. 1969-2009, Київ 2011.

Гончар О. Т., Щоденники, у 3-х томах, упоряд. В. Д. Гончар, т. 1 (1943-1967), т. 2 (19681983), т. 3 (1984-1995), Київ 2002, 2003, 2004.

Довженко О., Вибрані твори, упоряд. та передм. І. Л. Михайлина, Харків 2003.

Коваленко Л. М., „,Ми - люди майбутнього, ми - не минулі”, статті, рецензї, ияоденники, спогади, поезї, листи, упоряд, Н. Л. Калениченко, О. Б. Поліщук, Дніпродзержинськ 2008.

Космеда Т., Ego i Alter Ego Tapaca Шевченка в комунікативному просторі щзоденникового дискурсу, Дрогобич 2012.

Краткий психологический словарь, общ. ред. А. В. Петровского, М. Г. Ярошевского, Ростов-на-Дону 1998.

Літературознавча енииклопедія, у 2 томах, т. 2, авт.-уклад. Ю. І. Ковалів, Київ 2007.

Лотман Ю. М., Семиосфера: культура и взрыьв, Санкт-Петербург 2000.

Малик В. К., Синя книга, щзоденник (записки для себе). 1958-1998, упоряд. О. В. Сиченко, Н. О. Сиченко, Полтава 2010.

Николина Н. А., Поэтика русской автобиографической прозы, 3 изд., стереотип., Москва 2017.

Нора П., Проблематика мест памяти, Франция-память, пер. с фр. Д. Хапаева, СанктПетербург 1999.

Нуркова В. В., Зеркало с памятью. Феномен фотографии: культурно-исторический анализ, Москва 2006.

Нуркова В. В., Психология, ред. В. В. Нуркова, Н. Б. Березанская, 2-е изд., перераб. и доп., Москва 2011.

Нуркова В. В., Свершенное продолжается: Психология автобиографической памяти личности, Москва 2000.

Падучева Е. В., Семантика вида и точка отсчета, [в:] „Известия АН СССР, серия литературы и языка", Москва 1986, т. 45, № 5, с. 413-424.

Селіванова О. О., Лінгвістична енциклопедія, Полтава-Київ 2010.

Сорока Петро, Денники 2004-2005 років, Тернопіль 2006.

Сорока Петро, Душа при свічиі (Діяріюш Федора Жученка), Тернопіль 2002.

Сорока Петро, Застиглий вогонь. Денники 2006 року, Тернопіль 2007.

Сорока Петро, Рік подвійних райдуг. Денники 2002 року, Тернопіль 2003.

Танюк Л. С., Лінія життя (зі щоденників), у 2 томах, т. 2 (1971-1980), Харків 2004.

Чабаненко В. А., Стилістика експресивних засобів украйнської мови, моногр., Запоріжжя 2002.

Conway M. A., Memory and self, [v:] ,Journal Memory and Language”, 2005, 53, p. 594-628.

Conway M. A., Singer J. A. \& Tagini A., The Self and Autobiographical Memory: Correspondence and Coherence, [v:] „Social Cognition”, 2004, 22(5), p. 491-529. 


\section{Spysok vykorystanoi literatury \\ [References]}

Bahtin M. M., Problema rechevyh zhanrov [Problem of Speech Genres], [v:] E'stetika slovesnogo tvorchestva, sost. S. H. Bocharov, 2-e yzd., Moskva 1986.

Bondarevska I., Pamiataty $i$ zabuvaty. Ese pro polityku pamiati [To Remember and to Forget. Essay on Memory Policy], [v:] „Filosofska dumka”, 2014, № 6, s. 46-61.

Bragina N. G., Pamyat'v yazyke i kul'ture [Memory in Language Culture], Moskva 2007.

Vasil'ev L. M., Semantika russkogo glagola [Semantics of Russian Verb], Moskva 1981.

Velykyi tlumachnyi slovnyk suchasnoi ukrainskoi movy [Big Explanatory Dictionary of the Ukrainian Language], uklad. V. T. Busel, Kyiv 2004.

Volia Oles, Shchodennyk. Sorok rokiv. 1969-2009 [Diary. Forty Years. 1969-2009], Kyiv 2011.

Honchar O. T., Shchodennyky [Diaries], u 3-kh tomakh, uporiad. V. D. Honchar, t. 1 (19431967), t. 2 (1968-1983), t. 3 (1984-1995), Kyiv 2002, 2003, 2004.

Dovzhenko O., Vybrani tvory [Selected Works], uporiad. ta peredm. I. L. Mykhailyna, Kharkiv 2003.

Kovalenko L. M., „My - liudy maibutnoho, my - ne mynuli”, statti, retsenzii, shchodennyky, spohady, poezii, lysty ["We-People of the Future, We are not the Past", Articles, Reviews, Diaries, Recollections, Poetry, Letters], uporiad. N. L. Kalenychenko, O. B. Polishchuk, Dniprodzerzhynsk 2008.

Kosmeda T., Ego $i$ Alter Ego Tarasa Shevchenka $v$ komunikatyvnomu prostori shchodennykovoho dyskursu [Ego and Alter Ego of Taras Shevchenko in Communicative Space of Diary Discourse], Drohobych 2012.

Kratkij psihologicheskij slovar' [Concise Psychological Dictionary], obshh. red. A. V. Petrovskogo, M. G. Yaroshevskogo, Rostov-na-Donu 1998.

Literaturoznavcha entsyklopediia [Encyclopedia of Literature], u 2 tomakh, t. 2, avt.-uklad. Yu. I. Kovaliv, Kyiv 2007.

Lotman Yu. M., Semiosfera: kultura i vzryv [Semiosphere: Culture and Explosion], SanktPeterburh 2000.

Malyk V. K., Synia knyha, shchodennyk (zapysky dlia sebe). 1958-1998 [Blue Book, Diary (Notes for myself)], uporiad. O. V. Sychenko, N. O. Sychenko, Poltava 2010.

Nikolyna N. A., Poe`tika russkoj avtobiograficheskoj prozy [Poetics of Russian Autobiographic Prose], 3 yzd., stereotyp., Moskva 2017.

Nora P., Problematika mest pamyati, Franciya-pamyat [Problem of Memory Places, France Memory], per. s fr. D. Khapaeva, Sankt-Peterburh 1999.

Nurkova V. V., Zerkalo s pamyat'yu. Fenomen fotografii: kul'turno-istoricheskij analiz [Mirror with Memory. Phenomenon of Photography: Cultural, Historical Analysis], Moskva 2006.

Nurkova V. V, Psihologiya [Psychology], red. V. V. Nurkova, N. B. Berezanskaya, 2-e izd., pererab. i dop., Moskva 2011.

Nurkova V. V., Svershennoe prodolzhaetsya: Psihologiya avtobiograficheskoj pamyati lichnosti [What Happened is Going on: Psychology Autobiography Memory of Personality], Moskva 2000.

Paducheva E. V., Semantika vida i tochka otscheta [Semantics of Type and Starting Point], [v:] „Izvestiya AN SSSR, seriya literatury i yazyka”, Moskva 1986, t. 45, № 5, s. 413-424.

Selivanova O. O., Linhvistychna entsyklopediia [Linguistic Encyclopedia], Poltava-Kyiv 2010.

Soroka Petro, Dennyky 2004-2005 rokiv [Diaries 2004-2005 Years], Ternopil 2006.

Soroka Petro, Dusha pry svichtsi (Diiariiush Fedora Zhuchenka) [Soul in the Candle (Diary of Fedir Zhuchenko], Ternopil 2002.

Soroka Petro, Zastyhlyi vohon. Dennyky 2006 roku [Frozen Fire. Diary of 2006], Ternopil 2007.

Soroka Petro, Rik podviinykh raiduh. Dennyky 2002 roku [Year of Double Rainbows. Diary of 2002], Ternopil 2003. 
Taniuk L. S., Liniia zhyttia (zi shchodennykiv) [Life Line (based on Diaries)], u 2 tomakh, t. 2 (1971-1980), Kharkiv 2004.

Chabanenko V. A., Stylistyka ekspresyvnykh zasobiv ukrainskoi movy [Stylistics of Expressive Means in Ukrainian], monohr., Zaporizhzhia 2002.

Conway M. A., Memory and self, [v:] ,Journal Memory and Language”, 2005, 53, p. 594-628.

Conway M. A., Singer J. A. \& Tagini A., The Self and Autobiographical Memory: Correspondence and Coherence, [v:] ,Social Cognition”, 2004, 22(5), p. 491-529. 